\title{
AN OPTIMAL POSITIONING AND VOLTAGE STABILITY ANALYSIS OF RENEWABLE DISTRIBUTED GENERATION AND GRID INTEGRATED
} ENERGY SYSTEMS - A REVIEW

\author{
ARPITA DE ${ }^{1} \&$ ARVIND MITTAL ${ }^{2}$ \\ ${ }^{I}$ Research Scholar, Maulana Azad National Institute of Technology, Bhopal, India \\ ${ }^{2}$ Associate Professor, Maulana Azad National Institute of Technology, Bhopal, India
}

In the recent past, there has been an increased need for renewable sources of Distributed Generation (DG) in the electricity distribution systems. It is worth noting that rural areas in the most undeveloped and developing countries do not have access to electricity. In an attempt to solve this, there has developed an increased need to use Grids in order to distribute electricity in the remote areas. Where the Grids are not developed, the transportation costs are very high. Additionally, the capital costs for renewable sources and storage technologies had drastically gown down resulting into their popularity in the modern industry. The increased need for renewable energy systems has enhances the application of Distributed Generation resources which would aid the distribution procedures [1]. As the transportation costs of nonrenewable sources rise, the integration of the renewable sources with the Distribution Generation systems had brought it down. This paper aims at reviewing some of the literature works on this topic.
\end{abstract}

KEYWORDS: Distributed Generator, Optimal Positioning, Voltage Stability, Renewable Energy \& Grid.

Received: Jun 09, 2019; Accepted: Jun 29, 2019; Published: Jul 12, 2019; Paper Id.: IJEEERDEC20192

\section{INTRODUCTION}

Distribution companies need more efficient arranging systems request to fulfil the gauge burden need and to supply solid capacity to the buyers. In the present deregulation condition the customary development of extra substations to meet the heap development request isn't practical and utilities needs elective advances, for example, Distribution Generations (DGs). Due to the quick exhaustion of petroleum derivatives and to meet the cutting edge control framework rebuilding prerequisites, disseminated age turned into a quick choice. DG can be defined as the approach that employs small-scale technologies to produce electricity close to the end users of power. DG technologies often consist of modular (and sometimes renewable-energy) generators, and they offer a number of potential benefits"[2]. 


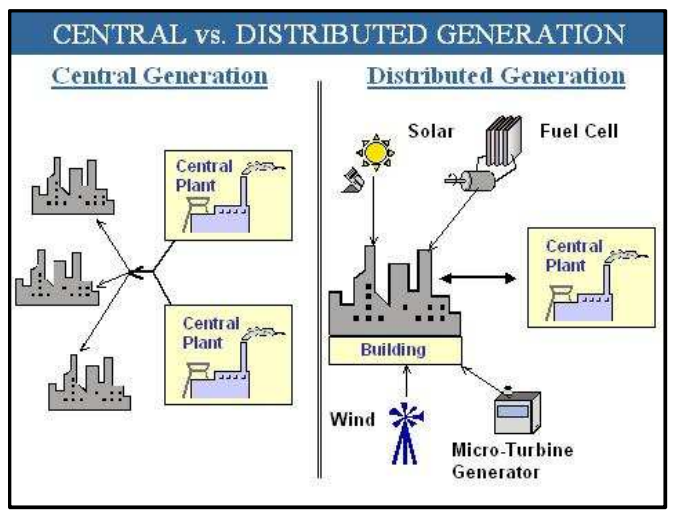

Figure 1: Central v/s Distributed Generation

Most industrially accessible DG innovations are wind controlled, solar photovoltaic based, and solar thermal along with biomass and small scale hydro energy systems. Dispersion arranges for the most part structured detached circuits to transport control from focal power station purchasers and consequently the rating and situating of DGs to be introduced ought to be considered with more prominent thought. Proper area and estimating of DG units in conveyance framework improves the voltage profile, supplies pinnacle burden request, and limits line loadings and responsive power prerequisite, and diminishes the system power loss.

Parallel to the presentation of DG; when circulation framework arranging and DG effect are considered, the best consideration ought to be paid in the siting and estimating of DG units in light of the fact that their establishment in nonideal areas can result both in an expanding of intensity misfortunes and in a lessening of unwavering quality dimensions. At that point legitimate devices, ready to find the siting and measuring of DG units which lessens at greatest the expenses while fulfilling specialized requirements can help for the organizer who needs to look with the overall development of DG entrance. From circulation framework arranging perspective, DG is a doable option for new limit particularly in the focused power advertise condition and has huge benefits [3].

\section{OPTIMAL POSITIONING}

Most of literature, authors have proposed ways in which stress problems could be reduced with the assumption that Distributed Generation as dispatchable. The Optimal Placing of the Distributed Generations has been highly researched on. It is worth noting that the popularity of the renewable energy sources has led to the appreciation of different types of Distributed Generations systems. The main reason behind this is their advantages in promoting both the environmental and technical effectiveness. For the effectiveness of the Distributed Generations, Optimal Positioning is vital in the integration of the former and the renewable sources. In this case, the integration of the two has resulted to their popularity in cutting cost and enhancing productivity.

Diverse sorts of inexhaustible Optimal Positioning DGs are utilized as a part of the dissemination framework. Among them, wind speed-and sun oriented irradiance-based inexhaustible DGs are the most prevailing and generally interconnected into the outspread dispersion framework. Henceforth, this paper considers these two inexhaustible DGs, i.e., wind speed-and sun oriented irradiance-based power era. [4] Exact wind and solar powered energy sources displaying is calm testing. The vast majority of the writing accepts a yearly mean for wind and sun oriented irradiance demonstrating which creates non-practical outcomes. Henceforth, most authors propose an hourly multi-state demonstrating, as it were that diverse conditions of every hour are handled through reasonable likelihood capacities, which ensure the best yield 
results and ideal stochastic displaying for the breeze and sun based irradiances. The authentic breeze speed and sun oriented irradiance information are utilized to show the breeze and sunlight based ranches as clarified in the accompanying areas.

\section{VOLTAGE STABILITY ANALYSIS}

The power misfortune minimization and voltage security change as multi-target streamlining are inquired about while considering the influence misfortune minimization, voltage profile change and voltage strength change as a multitarget enhancement issue. Distinctive optimization systems, for example, the dynamic pursuit calculation, weighted multitarget record. The entrance of sustainable power in the circulation framework is expanding straightly and the truth of the matter is that nothing from what was just mentioned creators presented inexhaustible DG.

In wind, solar, biomass energy unit and miniaturized hydel scale turbine type of DGs were used formulating objective DG positioning and sizing problems. Be that as it may, the yield energy of wind vitality and sun oriented PVs are irregular in nature, so expecting their yield control as dispatch able DG will adverse effect framework execution. The irregularity of wind and sun oriented power DG can be relieved with the assistance of vitality stockpiling.

In the modern world, the use of Renewable Distributed Generation and Central Grid Integrated Energy Systems has increased rapidly. The main reason behind this could be related to a number of environmental factors, the development on the electricity industry and the availability of power in small scale. As a result of these factors, there is increased interest in Distributed Generation especially in a case of Renewable power source. [5] As a result, there is development of integration between the Distributed Generation units and the distribution systems.

This has impacted the applicability and the pattern followed by voltage power, power reliability, stability, protection and flow. This impact has resulted into the integration of literature in an attempt to depict the current situation. Technological experts and engineering scholars have been quick to conduct research and present their findings in relation to the above topic. In addition, the literature has formed a platform that learners could reflect on in their quest to understand the topic in a far much better way.

Voltage stability refers to the general ability of a power system to maintain its providence of voltage in a constant and in an acceptable manner. Voltage stability is measured despite the existence of factors that could result into the disturbance of the power system. Cutsem \& Vournas [6] note that the main factor affecting voltage stability is its inability to meet the required power demand. Depending with the disturbance type, voltage stability could be grouped into either large or small.

Ong et al [5] noted that small voltage reliability simply refers to the ability of the power system to control, small occurrences such as small changes in the loads. On the other hand, the author notes that large stability is the ability of the system to control the voltage after it is subjected to large occurrences. This could include large changes in the loads or load outages among other happenings.

Voltage Regulation has become of major issue for the power utilities. Voltage fluctuations occur when system generation is not equivalent to the load demand. The connection of DGs in distribution networks has created a challenge for distribution network operators (DNOs) to change their obsolete approach to an active system approach. This is due to the fact that the traditional distribution networks are designed based on the assumption of single direction power flow path. 
With the increasing connection of DG, the network has become more spectacular with bidirectional power flow and now known to be Active Distribution Networks (ADN).

An active distribution network is defined as a distribution pathway to control a combination of distributed energy sources comprising of generators and storage measures [6].

Voltage Stability analysis on the Renewable energy sources has been used as an effective tool of analyzing the effectiveness of the latter. It is trusted that because of the unmistakable qualities of PV and current framework direction, the Voltage Stability security of the framework could significantly be influenced by high PV entrances. The impact of high PV infiltrations on the voltage extent and strength of the transmission and sub-transmission framework are contemplated in. The examination exertion in a number of sources uncover that relying upon the infiltrations of vast scale PV, the framework could encounter both beneficial and negative impacts from the enduring state dependability perspective.

\section{GRID INTEGRATION ISSUES [8]}

\section{Voltage Fluctuation and Regulation}

Voltage fluctuation is a change or swing in voltage, and can be problematic if it moves outside specified values. It affects the performance of many household appliances and can consist of variations in the peak and RMS (root mean square) voltage on the line. Supply authorities or government regulators generally stipulate the maximum acceptable deviation from the nominal voltage as seen by the customers. Effects on loads are usually noticed when the voltage fluctuates more than $10 \%$ above or below the nominal voltage, and the severity of the effects depend upon the duration of the change[9].

\section{Power Factor Correction}

Poor power factor on the grid increases line losses and makes voltage regulation more difficult. Inverters configured to be voltage - following are generally set to have unity power factor, while inverters in voltage-regulating mode provide current that is out of phase with the grid voltage and so provide power factor correction. This can be a simple fixed power factor or one that is automatically controlled by, for example, the power system voltage [10].

\section{Frequency Variation and Regulation}

Disruptions in the balance between supply and demand lead to frequency fluctuation-it falls when demand exceeds supply and rises when supply exceeds demand. Power systems contain a number of sources of inertia (e.g.larger rotating generators and motors), which result in considerable time constant involved in frequency movements when there is a mismatch between load and generation. The time constants depend of course on the size of the system and how well it is interconnected. Frequency regulation is maintained by control loops built in to the power generating sources on the network [11].

\section{Harmonics}

They are currents or voltages with frequencies that are integer multiples of the fundamental power frequency. The standard frequency is 50 or $60 \mathrm{~Hz}$ depending on the country, and so a harmonic in a $50 \mathrm{~Hz}$ country could be $100,150,200$ $\mathrm{Hz}$, etc. Electrical appliances and generators all produce harmonics and are regulated under the International Electro technical Commission (IEC) Electro-magnetic Interference (EMI) standards. However in large volumes (e.g. computers and compact fluorescent lamps), these harmonics can add up to cause interference that can result in vibration of elevators, 
flickering of TV monitors and fluorescent lamps, degradation of sound quality, malfunctioning of control devices and even fires[12].

\section{EVALUATING CRITERIONS FOR DESIGNING HYBRID ENERGY SYSTEMS [14]}

\section{Table 1}

\begin{tabular}{|c|c|c|c|}
\hline $\begin{array}{l}\text { S } \\
\text { No }\end{array}$ & Criterion & Purpose/scope for criterion & Measurable parameters \\
\hline \multirow[t]{7}{*}{1} & $\begin{array}{l}\text { Technological factors } \\
\text { - Feasibility }\end{array}$ & - Ensure the possibility of implementing HES & - Validating the results regularty \\
\hline & - Risk & $\begin{array}{l}\text { - Ensure the possibility of implementing HES by calculating the } \\
\text { number of problems associated during failures while testing of } \\
\text { the system }\end{array}$ & $\begin{array}{l}\text { - Number of problems experienced while encountering failures in a } \\
\text { tested system }\end{array}$ \\
\hline & - Reliability & $\begin{array}{l}\text { - The criterion estimates the technology of HES implemented HES } \\
\text { can be tested in laboratory or can be performed in the pilot } \\
\text { plants, or it could be still improved before implementing during } \\
\text { simulation, considering various parameters }\end{array}$ & $\begin{array}{l}\text { - The effectiveness of the system for serving a variable load in } \\
\text { accordance with time }\end{array}$ \\
\hline & $\begin{array}{l}\text { - The duration of } \\
\text { preparation phase }\end{array}$ & $\begin{array}{l}\text { - The criterion calculates the availability of the renewable energy } \\
\text { potential in the locality, alternative to decrease the financial } \\
\text { assets and reach the minimum cost }\end{array}$ & $\begin{array}{l}\text { - The cost of the implementation phase is judgment by taking into } \\
\text { accounts years or months of implementation }\end{array}$ \\
\hline & $\begin{array}{l}\text { - The duration of } \\
\text { implementation phase }\end{array}$ & $\begin{array}{l}\text { - The criterion evaluates the applicability of HES alternative to } \\
\text { reach the minimum cost. }\end{array}$ & $\begin{array}{l}\text { - The cast of the implementation phase is judgment by taking into } \\
\text { accounts years or months of implementation }\end{array}$ \\
\hline & $\begin{array}{l}\text { - Community and } \\
\text { predictability of } \\
\text { performance }\end{array}$ & - This criterion evaluates the operation and performance of the HES & $\begin{array}{l}\text { - It is important to know if the technology operates continuously } \\
\text { and confidently }\end{array}$ \\
\hline & $\begin{array}{l}\text { - Local technical } \\
\text { know how }\end{array}$ & $\begin{array}{l}\text { - This criterion includes the evaluation which is hased on a } \\
\text { qualitative comparison between the complexity of the considered } \\
\text { technology and the capacity of the local actors }\end{array}$ & $\begin{array}{l}\text { - It ensures an appropriate operating support for maintenance and } \\
\text { ins tallation of technology for renewable energy alternative }\end{array}$ \\
\hline \multirow[t]{4}{*}{2} & Economic factors & & \\
\hline & - Implementation cost & $\begin{array}{l}\text { - This criterion analyzes the total cost of the energy investment in } \\
\text { order to be fully operational }\end{array}$ & - Total cost of the system \\
\hline & - Availability of funds & $\begin{array}{l}\text { - This criterion evaluates the national and international sources of } \\
\text { funds, and economic support of government }\end{array}$ & - Various factors present in a country or organization \\
\hline & $\begin{array}{l}\text { - Economic value } \\
\text { (PW, IRR, BjC) }\end{array}$ & $\begin{array}{l}\text { - This criterion judges the proposed renewable energy alternative } \\
\text { as economically }\end{array}$ & $\begin{array}{l}\text { - It uses engineering economics techniques which are present } \\
\text { worth (PW), internal ratre of return (IRR), benefit/cost analysis (B) } \\
\text { C), and payback period (PP) }\end{array}$ \\
\hline \multirow[t]{5}{*}{3} & Socio political factors & & \\
\hline & $\begin{array}{l}\text { - Compatibility with the } \\
\text { national energy policy } \\
\text { objectives }\end{array}$ & $\begin{array}{l}\text { - The criterion analyses the integration of the national energy } \\
\text { policy and the suggested renewable energy alternative }\end{array}$ & $\begin{array}{l}\text { - It measures the degree of objectives' convergence between the } \\
\text { government policy and the suggested poticy. The criterion also } \\
\text { takes into account the government's support, the tendency of } \\
\text { institutional actors, and the policy of public information }\end{array}$ \\
\hline & - Political acceptance & $\begin{array}{l}\text { - The criterion searches whether or not a consensus among leader's } \\
\text { opinions for proposed renewable energy alternative exists. Also it } \\
\text { takes intb account avoiding the reactions of the politicians and } \\
\text { satisfying political leaders }\end{array}$ & - Policy implementation \\
\hline & - Social acceptance & $\begin{array}{l}\text { - The criterion enhances consensus among sodial partners. Asso it } \\
\text { takes into account avoiding the reactions from special interest } \\
\text { special groups for renewable energy alternatives }\end{array}$ & - Public participation \\
\hline & - Labor impact & $\begin{array}{l}\text { - Renewable energy alternatives are evaluated taking into account } \\
\text { labor impact }\end{array}$ & $\begin{array}{l}\text { - It is related to direct and indirect employments and the possible } \\
\text { indirect creation of new professional figures are also assessed }\end{array}$ \\
\hline \multirow[t]{4}{*}{4} & Environmental factors & & \\
\hline & - Pollutant emission & $\begin{array}{l}\text { - The criterion measures the equivalent emissions of } \mathrm{CO}_{2} \text {, air } \\
\text { emissions which are the results of the combustion process, liquid } \\
\text { wastes which are related to secondary products by fumes } \\
\text { treatment or with process water, and solid wastes }\end{array}$ & $\begin{array}{l}\text { - The evaluation of the criterion includes type and quantity of } \\
\text { emissions, and costs associated with wastes treatments. Also, the } \\
\text { electro-magnetic interferences, bad smells, and micodimatic } \\
\text { changes for energy investments are taken into account in the } \\
\text { evaluation of this citerion }\end{array}$ \\
\hline & - Land requirement & $\begin{array}{l}\text { - Land requirement is one of the most critical factors for energy } \\
\text { investment }\end{array}$ & - A strong demand for land can also determine the energy bsses \\
\hline & - Need of waste disposal & $\begin{array}{l}\text { - The criterion evaluates the renewable energy's damage on the } \\
\text { quality of the environment }\end{array}$ & $\begin{array}{l}\text { - The renewable energy alternative can be evaluated to reduce } \\
\text { damage on the quality of life and to increase the sustainability by } \\
\text { taking into account this criterion }\end{array}$ \\
\hline
\end{tabular}


SUMMARY OF AVAILABLE SOFTWARE TOOLS FOR UNIT SIZING OF HYBRID ENERGY SYSTEMS [15]

Table 2

\begin{tabular}{|c|c|c|c|c|}
\hline $\begin{array}{l}\text { S. } \\
\text { No. }\end{array}$ & $\begin{array}{l}\text { Software } \\
\text { tools }\end{array}$ & Input & Output & Availibility \\
\hline 1 & HOMER & $\begin{array}{l}\text { - Load demand } \\
\text { - Resource input } \\
\text { - Component details including capital, maintenance } \\
\text { and replacement cost } \\
\text { - System control }\end{array}$ & $\begin{array}{l}\text { - Optimal unit sizing } \\
\text { - Cost of energy, net present cost } \\
\text { - Fraction of renewable energy }\end{array}$ & $\begin{array}{l}\text { Free } \\
\text { www.homerenergy.com }\end{array}$ \\
\hline$p$ & HYBRID2 & $\begin{array}{l}\text { - Load demand } \\
\text { - Resources input } \\
\text { - Initial investment and O\&M Cost of system } \\
\text { components } \\
\text { - Components details }\end{array}$ & $\begin{array}{l}\text { - Unit sizing with cost optimization } \\
\text { - cost of energy } \\
\text { Emissions in terms of percentage of various } \\
\text { greenhouse gases } \\
\text { - System payback periods }\end{array}$ & $\begin{array}{l}\text { Free } \\
\text { http://www.ceere.org/rerl/ } \\
\text { rerl_hybridpower.html }\end{array}$ \\
\hline 3 & HYBRIDS & $\begin{array}{l}\text { - Size of solar array } \\
\text { - Wind turbine type } \\
\text { - Quantity and type of battery }\end{array}$ & $\begin{array}{l}\text { - Cost of energy } \\
\text { - Percentage emission of various greenhouse gases }\end{array}$ & - \\
\hline 4 & $\begin{array}{l}\text { RET } \\
\text { Screen }\end{array}$ & $\begin{array}{l}\text { - Load data } \\
\text { - Size of Solar Array } \\
\text { - Required hydrology and product database } \\
\text { - Climate database }\end{array}$ & $\begin{array}{l}\text { - Energy production and savings } \\
\text { - Costs } \\
\text { - Emission reductions } \\
\text { - Financial viability } \\
\text { - Sensitivity and risk analysis }\end{array}$ & $\begin{array}{l}\text { Free } \\
\text { http://www.retscreen.net/ }\end{array}$ \\
\hline 5 & IHOGA & $\begin{array}{l}\text { - Load data } \\
\text { - Resources input data } \\
\text { - Component and economics details }\end{array}$ & $\begin{array}{l}\text { - Multi objective optimization } \\
\text { - Cost of energy } \\
\text { - Life cycle emission } \\
\text { - Analysis for buy and sell of energy }\end{array}$ & $\begin{array}{l}\text { PRO version is priced \& EDU } \\
\text { version is free } \\
\text { http://www.unizares/rdufo/ } \\
\text { hoga-enghtm }\end{array}$ \\
\hline 6 & TRNSYS & $\begin{array}{l}\text { - Meteorological data input of resources } \\
\text { - Inbuilt models }\end{array}$ & $\begin{array}{l}\text { - Provide the dynamic simulation results of electrical } \\
\text { and thermal energy system }\end{array}$ & $\begin{array}{l}\text { Priced } \\
\text { http://www.trnsys.com/ }\end{array}$ \\
\hline
\end{tabular}

\section{CASE STUDY}

The creators in Voltage Stability analysis broke down the impact of vast scale PV on static Voltage Stability of the Ontario control framework with concentrated and circulated PV. The examination has been finished by considering different infiltration levels up to 2000MW. Their examination reasoned that scattered PV in Ontario framework may beneficially influence the static voltage steadiness of the framework. The Ontario utility experienced less beneficial impact regarding Voltage Stability edge change if the PVs are focal power plant sort. In this work, the beneficial impact of PV on VOL steadiness has been converted into the monetary benefit to the framework. From the investigation it is clear that longrun reserve funds from load ability improvement are higher for the distributed PV framework when contrasted with the brought together PV with voltage and responsive power control. [13]

In Voltage Stability analysis especially on micro grid, it would be important to put into consideration some of the most important factors surrounding the entire procedure. It is important to reflect on the integration issues

- Voltage rise and power flow

- Voltage imbalance

- Power fluctuations

- Unintentional Islanding

The above issues arise in the integration of the Grid and the Distributed Generation systems. In a case their effectiveness is required, it would be important to reflect on their general effect on Voltage Stability and Optimal Positioning. 


\section{CONCLUSIONS}

This paper attempts to present the state of art of research work carried out on the optimal planning of distributed generation (DG) systems under different aspects. There are number of important issues to be considered while carrying out studies related to the planning and operational aspects of DG. The planning of the electric system with the presence of DG requires the definition of several factors, such as: the best technology to be used, the number and the capacity of the units, the best location, the type of network connection, etc. The impact of DG in system operating characteristics, such as electric losses, voltage profile, stability and reliability needs to be appropriately evaluated. For that reason, the use of an optimization method capable of indicating the best solution for a given distribution network can be very useful for the system planning engineer, when dealing with the increase of DG penetration that is happening nowadays. The selection of the best places for installation and the preferable size of the DG units in large distribution systems is a complex combinatorial optimization problem.

On the whole, the various methodologies involved in the DG placement by researchers revealed that when finding a global optimal solution of complex multi-objective optimization problems, particularly those with many local optima. One is generally faced with a fundamental conflict between accuracy, reliability and computational time. It is often impossible to arrive at solution that optimizes all objectives without a trade- off. Consequent upon that fact, it is concluded that hybrid of two or more optimization techniques would yield a more efficient and reliable optimal solution. By so doing, the techniques would have combined their strength and mitigate each other's limitations in arriving at the best possible solutions. The uncertainties involved in system planning and operation become larger and certainly new methods need to be developed to analyze and to foresee the behaviour of the systems.

\section{REFERENCES}

1. Ackermann, T., Andersson, G., \& Soder, L. (2001). Distributed generation: a definition. Electric power systems research, 57(3), 195-204.

2. Wikipedia https://www.google.com/search?q=distributed + generation \&oq=distributed + ge \&aqs =chrome.0.0j69i57j0l4.5977j1j7\&source $\underline{i d}=$ chrome $\& i e=U T F-8$

3. Rajkumar Viral, D.K. Khatod, (2012) Optimal planning of distributed generation systems in distribution system - A review, Renewable and Sustainable Energy Reviews, 16, 5146-5165

4. Begovic, M., Pregelj, A., Rohatgi, A., \& Novosel, D. (2001, January). Impact of renewable distributed generation on power systems. In System Sciences, 2001. Proceedings of the 34th Annual Hawaii International Conference on (pp. 654-663). IEEE.

5. Ong, S. P., Chevrier, V. L., Hautier, G., Jain, A., Moore, C., Kim, S. \& Ceder, G. (2011), Voltage, stability and diffusion barrier differences between sodium-ion and lithium-ion intercalation materials. Energy \& Environmental Science, 4(9), 36803688 . 
6. Van Cutsem, T., \& Vournas, C. (2008). Voltage stability of electric power systems (Vol. 441). Springer Science \& Business Media.

7. Arpita De \& Arvind Mittal, Aug 2014, Stability And Optimization of Distributed Generation: A Review, International Journal of Electrical and Electronics Engineering Research (IJEEER), ISSN(P): 2250-155X; ISSN(E): 2278-943X

8. Robert Passey, TedSpooner, IainMacGill, MurielWatt, KaterinaSyngellakis ;(2011), The potential impacts of grid-connected distributed generation and how to address them: A review of technical and non-technical factors,Energy Policy 39 (2011) 6280-6290

9. Archer, C.L., Jacobson, M.Z., 2005. Evaluation of global wind power. Journal of Geophysical Research 110 , D1211. doi:10.1029/2004JD005462

10. Denholm, P., Ela, E., Kirby, B, Milligan, M., 2010. The role of energy storage with renewable electricity generation. NREL Technical Report NREL/TP-6A2-47187, January 2010

11. Fiji Electricity Authority, 2010. Fiji's renewable energy power development plan, Hasmukh Patel, Chief Executive Officer. Presentation to the Fiji National University (FNU) Symposium on Renewable Energy Technologies, Suva, Fiji, October 2010

12. Sara, Z., \& El Habib, B. S. M. The Impact of Renewable Energy in Urban Planning Instruments the Case of the PDAU.

13. Trujillo, C.L.,Velasco,D.,Figueres,E.,Garcera' , G.,2010.Analysisofactiveislanding detection methodsforgridconnectedmicroinvertersforrenewableenergy processing. AppliedEnergy87,p3591-3605.

14. Manz, D., Schelenz, O., Chandra, R., Bose, S., de Rooij, M., Bebic, J., 2008. Enhanced Reliability of Photovoltaic Systems with Energy Storage and Controls. GE Global Research Niskayuna, New York.

15. Subho Upadhyay, M.P.Sharma, (2014), A reviewonconfigurations, controlandsizingmethodologies of hybridenergysystems, RenewableandSustainableEnergyReviews38, 47-63

16. Thakur, Robin., Suri, A. R. S., Kumar, S., \& Kumar, A. N. I. L. (2013). A review of integrated renewable energy system in power generation. Int J Mech Prod Eng Res Technol, 3, 79-88.

17. Sao CK, Lehn PW.A transformer less energy storages stem based on a cascade multilevel PWM converter with star configuration. IEEE Trans Ind Appl 2008;44(5):1621-30. 